\title{
BACTERIAL PATTERN OF APPENDIX IN ACUTE AND CHRONIC APPENDICITIS WITH ITS CLINICAL CORRELATION
}

\author{
Surajit Lahiri ${ }^{1}$
}

${ }_{1}^{1}$ Associate Professor, Department of Surgery, ESI-PGIMSR \& ESIC Medical College, Joka.

\begin{abstract}
\section{BACKGROUND}

Acute appendicitis is a common, sometimes confusing and often treacherous cause of acute abdomen at all ages. The only way to reduce morbidity and to prevent mortality is to perform appendicectomy before perforation or gangrene occurs. As appendicectomy is a very common practice, it is essential to know in detail the various etiological factors that precipitate appendicitis. Bacterial invasion being a very common cause makes it imperative that we have a clear picture of the bacterial pattern of appendix in acute and recurrent appendicitis and to correlate this with clinical findings. A proper idea of bacterial flora of appendix thus helps us not only to prevent postoperative complication, but also to impart effective conservative treatment by pinpointing sensitive drugs.
\end{abstract}

\section{AIMS AND OBJECTIVES}

Knowledge of bacterial flora of appendix also has socio-economic benefits through low rates of post-operative complications, reduced hospital stay and also reduced indiscriminate use of multiple costly drugs. The aim of this study is to establish the bacterial profile in acute as well as recurrent appendicitis and to correlate the findings with the severity of the disease.

\section{MATERIALS AND METHODS}

This study was conducted on 90 patients irrespective of age and sex who attended the emergency and OPD during the course of the work with symptoms suggestive of appendicitis. Following appendicectomy, each of the specimens was cut into two pieces. One was sent for histopathological examination and other was sent for bacterial culture.

\section{RESULT}

The commonest bacteria isolated were Escherichia coli in $67.78 \%$ cases, which is a facultative anaerobe and it was closely accompanied by Klebsiella species in $47.78 \%$ cases. Other isolates that were recorded included Staphylococcus aureus in $3.33 \%$ cases with Pseudomonas aeruginosa and Proteus species in $2.22 \%$ cases each. Mixed infections were seen in phlegmonous, gangrenous and perforative appendicitis. Bacteroides fragilis was the most common obligate anaerobic isolate found in $40 \%$ of cases.

\section{CONCLUSIONS}

Commonest post-operative complications of appendicitis were superficial thrombophlebitis, wound infection and superficial wound dehiscence. This study helped to get a clear picture of appendiceal microbes of each patient, which can help to pinpoint effective antibiotics by culture and sensitivity test to reduce their post-operative complications.

\section{KEYWORDS}

Appendicitis, Appendicectomy, Bacterial pattern, Escherichia coli, Klebsiella pneumonia, Staphylococcus aureus, Pseudomonas aeruginosa, Proteus species, Bacteroides fragilis, Phlegmonous appendicitis, Gangrenous appendicitis, Perforative appendiciti s.

HOW TO CITE THIS ARTICLE: Lahiri S. Bacterial pattern of appendix in acute and chronic appendicitis with its clinical correlation. J. Evolution Med. Dent. Sci. 2016;5(10):418-421, DOI: 10.14260/jemds/2016/96

\section{INTRODUCTION}

Acute appendicitis is one of the most frequent conditions that lead to emergency abdominal surgery. It is essential to know in detail the various etiological factors.[1] Bacterial invasion being a very common cause makes it imperative that we have a clear picture of the bacterial pattern of appendix in acute and recurrent appendicitis and to correlate this with clinical findings.[2] The appendix is a tubular, worm-like (Vermiform) organ of the large intestine arising from caecum near the ileocaecal junction. $[2,3]$

Financial or Other, Competing Interest: None.

Submission 21-12-2015, Peer Review 14-01-2016,

Acceptance 21-01-2016, Published 03-02-2016.

Corresponding Author:

Dr. Surajit Lahiri,

Flat No. A - 7/8, E.K.T.P. (Phase-I),

E. M. Bypass, Kolkata-700107.

E-mail: drslahiri@yahoo.co.in

DOI: $10.14260 /$ jemds/2016/96
The human vermiform appendix is usually referred to as "A vestigial organ with no known function." Acute appendicitis can be either non-obstructive or obstructive in nature. [4] The cause of non-obstructive appendicitis is bacterial invasion of the lymphoid tissue in the appendix wall.[5] As the lumen of appendix is not obstructed, these cases are less liable to proceed on to gangrene and in many instances the acute attack will resolve spontaneously.[6] At times the swelling of the lymphoid tissue in the wall may lead to luminal obstruction and gangrene.[7,8] The basic pathological process in appendicitis is obstruction, usually by an impacted faecal matter, which is referred to faecolith. The appendix becomes a closed loop bowel.[9] Obstruction leads to bacterial overgrowth which results in a sudden rise in intraluminal hydrostatic pressure with vascular obstruction. ${ }^{[10]}$ These lead to congestion and ischemia in the appendix due to blood vessel thrombosis allowing bacterial translocation and resulting in inflammation of appendix. As the infection progresses, the inflammation advances to gangrene and perforation (As the 
blood supply of appendix is an end artery).[11] Consequently inflammatory fluid and bacterial contents spill and release into abdominal cavity. Both aerobic and anaerobic, gram-negative and gram-positive bacteria have been reported to be implicated in appendicitis such as Escherichia coli, Klebsiella species, Staphylococcus aureus, Pseudomonas aeruginosa, Beta-hemolytic streptococci, Proteus species and Bacteroides fragilis. Several studies have been made of the peritoneal fluid and bacterial pattern of appendix fossa.[11]

Wound infection is a common complication following appendicectomy. It ranges from $5 \%$ in cases of early inflammation to $75 \%$ if appendix is gangrenous or perforated when proper antibiotic therapy is not administered.[12] So this study was designed for patients who were diagnosed with acute and recurrent appendicitis in emergency and chronic ward and also undergone appendicectomy to correlate the bacterial flora with the severity of appendicitis.[12,13]

\section{AIMS AND OBJECTIVES \\ Knowledge of bacterial flora of appendix has socio-economic benefits through low rates of post-operative complications. It reduces hospital stay of the patients and also it can reduce indiscriminate use of multiple costly drugs by culture and sensitivity of the bacteria isolated. ${ }^{[13,14]} \mathrm{A}$ proper knowledge of bacterial flora of appendix also helps us to impart effective conservative treatment by pin-pointing sensitive drugs. The aim of this study is to establish the bacterial profile in acute as well as recurrent appendicitis and to correlate the findings with the severity of the disease.}

\section{MATERIALS AND METHODS}

This study was carried out on 90 patients of age varying 7-60 years who attended emergency as well as surgery OPD. Patients suspected of having acute and recurrent appendicitis were included in the study. On presentation, a detailed history and thorough clinical examination was done. Patients requiring operation were given proper pre-operative before operation. Following appendicectomy, the specimens of appendix was cut into two pieces. One piece was kept in formalin and sent for histopathological examination for confirmation of clinical diagnosis.

The other piece was preserved in a sterile test-tube containing Robertson-cooked media and sent for bacterial culture. In the laboratory, the samples were incubated at 36$37^{\circ} \mathrm{C}$ for 48 hours under aerobic and anaerobic conditions with anaerobic gas pack for another 48 hours. Bacterial culture resulted in the growth of one or several strains from each appendix. Positive colonies were Gram stained and any Gramnegative rods were tested against metronidazole and gentamicin discs to identify the different isolates. Culture reports were correlated with their histopathological reports of the specimens and results were analysed statistically.

\section{RESULTS AND ANALYSIS}

A total of 90 patients were included in this study, which comprised of 23 males and 67 females in a range of 7-60 years. Bacterial culture resulted in the growth of one or several strains from each appendix. The isolates are listed below along with the number of cases in which they were found. Often mixed strains were found at culture.
Figure-I shows percentages of cases out of a total of 90 patients from which different types of bacteria were isolated. The commonest isolate was Escherichia coli (facultative anaerobe) in $67.78 \%$ cases. It was closely accompanied by Klebsiella species in $47.77 \%$ cases, Staphylococcus aureus in $3.33 \%$ cases, Pseudomonas aeruginosa and Proteus species in $2.22 \%$ cases each. Bacteroides fragilis was the most common obligate anaerobic isolate and was found in $40 \%$ of cases. There was no growth of any bacteria in $6 \%$ of cases.

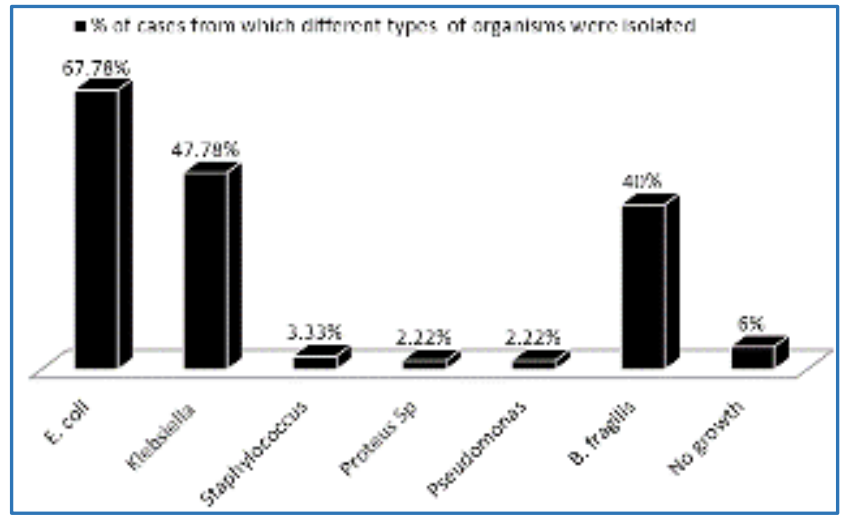

Fig. I: Types of organisms isolated $(n=90)$

In the course of the study, it was found that the time interval between the onset of symptoms of appendicitis and the patient presenting at the emergency ward was also variable to a great extent. A few patients reached early and their prognosis was good. Often the patients presented one or more days later. Table-I tries to search for a relation between the duration of illness and the bacterial flora found on culture of appendix.

\begin{tabular}{|c|c|c|}
\hline $\begin{array}{c}\text { Duration of } \\
\text { Illness (hrs) }\end{array}$ & $\begin{array}{c}\text { Number of } \\
\text { Cases }\end{array}$ & Bacteria Isolates \\
\hline$<6$ & 9 & E. coli \\
\hline $6-12$ & 33 & E. coli + Klebsiella sp \\
\hline $12-24$ & 20 & $\begin{array}{c}\text { E. coli + Klebsiella sp } \\
+ \text { B. fragilis }\end{array}$ \\
\hline$>24$ & 28 & $\begin{array}{c}\text { E. coli + Klebsiella sp } \\
+ \text { B. fragilis }\end{array}$ \\
\hline \multicolumn{2}{|c|}{ Table I: Duration of illness and bacterial } \\
flora (n= 90)
\end{tabular}

Per operative findings was also an important matter of this study. The macroscopic nature of appendix was noted to compare with the clinical diagnosis and bacteriology. The commonest variety of appendix at operation was phlegmonous type (42.22\%) followed closely by perforated type (15.56\%) and gangrenous type (13.33\%). A normal appendix was found in $11.11 \%$ of cases. Table II records these findings.

Table II also records the number of cases having postoperative complications amongst the various inflammatory conditions of appendix found at operation and their bacterial isolate on culture. 


\begin{tabular}{|c|c|c|c|c|}
\hline \multirow{2}{*}{ Type of Appendix } & \multirow{2}{*}{ Number of Cases } & \multicolumn{2}{|c|}{ Post-Operative Complication } & \multirow{2}{*}{ Bacteria Isolated } \\
\hline & & Number & Type & \\
\hline Catarrhal type & $11(12.22 \%)$ & $2(2.22 \%)$ & UTI, TH & E. coli \\
\hline Phlegmonous type & $38(42.22 \%)$ & $5(5.55 \%)$ & UTI, TH, WI & E. coli, Klebsiella, B. fragilis \\
\hline Gangrenous type & $12(13.33 \%)$ & $4(4.44 \%)$ & WI, WD, PI, TH & $\begin{array}{l}\text { E. coli, Klebsiella, B. fragilis, } \\
\text { others }\end{array}$ \\
\hline Perforative type & $14(15.56 \%)$ & $6(6.67 \%)$ & WI, WD, PI, P, IO & E. coli, B. fragilis \\
\hline Lump & $5(5.56 \%)$ & $2(2.22 \%)$ & UR, WD & E. coli, Pseudomonas \\
\hline Histologically normal & $10(11.11 \%)$ & $1(1.11 \%)$ & $\mathrm{TH}$ & E. coli, Klebsiella \\
\hline \multicolumn{5}{|c|}{ Table II: Post-operative complications and bacterial culture $(n=90)$} \\
\hline
\end{tabular}

UTI-Urinary tract infection, TH-Thrombophlebitis of superficial vein, WI-Superficial wound infection,

WD-Superficial wound dehiscence, PI-Paralytic ileus, UR- Urinary retention, P-Pneumonia, IO-Intestinal obstruction.

Figure II shows the relationship between different types of appendix according to the per-operative findings of our study with the number of complications recorded in each category. Normal appendix was found in $11.11 \%$ of cases, which was later confirmed by histopathological examinations. It may be noted that if the rate of incidence of normal appendix is $<15 \%$ of the total number of cases operated, it is acceptable worldwide.

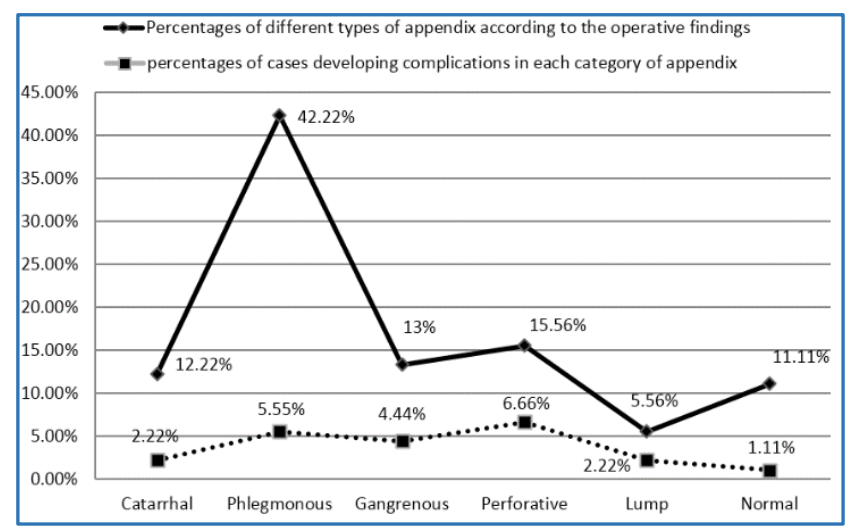

Fig. II: (n=90) Comparison between types of appendix and post-operative complications $(n=90)$

Finally, the patients were followed up for any postoperative complications. There were cases of mild UTI, wound infection or paralytic ileus. A few had gross wound infection of which three had superficial wound dehiscence that required secondary sutures. Some had thrombophlebitis of superficial veins, while others had urinary retention post-operatively. One grossly infected patient developed pneumonia and only one had sub-acute intestinal obstruction six months after operation. However, there was no mortality in any of the studied cases. Table III shows the incidence of each type of complications of the patients during this study.

\begin{tabular}{|c|c|}
\hline Type of Complications & $\begin{array}{c}\text { Number of cases that } \\
\text { had post-operative } \\
\text { complications (n=90) }\end{array}$ \\
\hline Wound infection (WI) & $5(5.55 \%)$ \\
\hline $\begin{array}{c}\text { Superficial wound } \\
\text { dehiscence (WD) }\end{array}$ & $3(3.33 \%)$ \\
\hline $\begin{array}{c}\text { Thrombophlebitis of } \\
\text { superficial vein (TH) }\end{array}$ & $5(5.55 \%)$ \\
\hline Paralytic ileus (PI) & $2(2.22 \%)$ \\
\hline Urinary retention (UR) & $1(1.11 \%)$ \\
\hline
\end{tabular}

\begin{tabular}{|c|c|}
\hline Urinary tract infection (UTI) & $2(2.22 \%)$ \\
\hline Pneumonia (P) & $1(1.11 \%)$ \\
\hline $\begin{array}{c}\text { Intestinal obstruction } \\
\text { (IO, } 6 \text { months after } \\
\text { operation) }\end{array}$ & $1(1.11 \%)$ \\
\hline $\begin{array}{c}\text { Table III: Incidence of different types of post-operative } \\
\text { complication (n = 90) }\end{array}$ \\
\hline
\end{tabular}

\section{DISCUSSION}

The study comprises of thorough clinical check-up and history taking of ninety patients who attended the emergency and surgery OPD during the course of the study. All of them were diagnosed as appendicitis and were admitted for it. Following appendicectomy, all the specimens were sent for bacteriological examination and the bacterial flora thus isolated were compared with the history, clinical signs and symptoms and were correlated with per-operative findings and subsequent histological study. On culture there were growth of a variety of microbes and these findings are described in Figure I.

Commonest organism isolated was Escherichia coli, a facultative anaerobe, found in $67.78 \%$ cases. It was closely followed by Klebsiella species in $47.78 \%$ cases. Staphylococcus aureus in $3.33 \%$ cases with Pseudomonas aeruginosa and Proteus species in $2.22 \%$ cases each. Bacteroides fragilis was the most common obligate anaerobic isolate found in $40 \%$ of cases. Thus we observe that the bacterial isolates found from the inflamed organ are the normal flora of the bowel. So there must have been secondary invasion of damaged tissue from the lumen of the bowel.

Table I shows the relation between the duration of illness and the bacterial flora isolated. Bacteriology of patients operated early showed only E. coli. With time we got multiple isolates, mainly E. coli, Klebsiella sp. and B. fragilis from each specimen.

Finally, a thorough study was made to correlate the postoperative complications that occurred with the type of appendix according to per-operative and histological findings and the bacterial isolate identified on culture. Table II and Figure II records the same. E. coli was a common isolate found in both normal and grossly inflamed appendix. Klebsiella sp. was common in phlegmonous and gangrenous type, while Bacteroides fragilis was found in phlegmonous, gangrenous and perforative type. Thus Bacteroides fragilis was more common in septic appendix.

Table III shows the common complications that were found in the study group. Wound infection, superficial wound dehiscence, thrombophlebitis of superficial veins, paralytic ileus, urinary retention, urinary tract infection, pneumonia 
and a single case of sub-acute intestinal obstruction was found after 6 months of operation. Of these superficial thrombophlebitis and wound infection were the commonest complications, which were followed by superficial wound dehiscence. E. coli was a common factor isolated from all complications. Bacteroides fragilis was mainly isolated from the cases of wound dehiscence and also from a case of postoperative pneumonia, which suggests that it has a significant role in septic complications. Pseudomonas aeruginosa was isolated from a case of early appendicular lump. Hence, grossly inflamed appendix tending towards lump formation makes us think of isolates other than the commoner ones.

\section{CONCLUSION}

From the study we can conclude that E. coli was the commonest organism isolated, followed closely by Klebsiella $\mathrm{sp}$. and Bacteroides fragilis. With increase in duration of the disease, the number of different types of bacteria isolated increased. E. coli was the commonest isolate from all cases that had post-operative complications, while B. fragilis had a significant role in septic complications. So knowledge of bacterial flora of appendix has socio-economic benefits through low rates of post-operative complications. It can reduce hospital stay and by pinpointing effective antibiotics by culture and sensitivity, it also reduce the indiscriminate use of multiple costly drugs.[15,16] A proper knowledge of bacterial flora of appendix also helps us to impart effective conservative treatment by using sensitive drugs. Moreover, $10 \%$ of patients whose appendix was found to be normal at operation and at histopathology had post-operative complication, which once again indicates that a patient should earn his operation as no operation is free of any risk of complication.

\section{REFERENCES}

1. WHO, Map of graphic: Countries by Mortality, Acute appendicitis, 2004.

2. Joubori AK. Acute appendicitis, clinical, histopathological and bacteriological study. 1994;70:38-41.

3. Anderson A, Berghahi I. Acute appendicitis in patients over 60. Ann Surg 1978;44:445-7.
4. Shelton T, Lefering R, Schwartz RW. Acute appendicitis, current diagnosis and treatment.

Ann Surg 2003;60:502-5.

5. Gilbert DN, Moellering RC, Sande MA. The Sanford guide to antimicrobial therapy, Hyde Park, Vermont: Antimicrob Ther Inc 2002;55:314-6.

6. Jacobsen J, Andersen JC, Klausen IB. Beta-haemolytic streptococci in acute appendicitis. Acta Chir Scand 1987;154:29-32.

7. Okoro I, et al. The role of Yersinia enterocolitica in appendicitis in Zaria. East Afr Med J 1988;65:625-7.

8. Guasco C, Roncheto F, Milani P, et al. Bacteriology of abdominal pus in 43 cases of acute appendicitis and appendicular abscess at the Ivra-Castellamonate Hospital: isolation of aerobic and anaerobic bacteria and drug sensitivity. J Bacteriol Virol-Immunol 1991;84:7780.

9. Leigh DA, Simmon K, Norman E. Bacterial flora of appendix fossa in appendicitis and post-operative wound infection. J Clin Path 1974;27:997-9.

10. Bailey and Love. Short Practice of Surgery. 26th ed. US: CRC Press, Francis and Taylor Group; 2013. p. 12011202.

11. Altemeier WA. The bacterial flora of acute perforated appendicitis with peritonitis: a bacteriologic study based upon one hundred cases. Ann Surg 1938;107:517-28.

12. Bennion RS; Baron EJ; Thompson JE, Jr; et al. The bacteriology of gangrenous and perforated appendicitis - revisited. Ann Surg 1990;211:165-71.

13. Roberts JP. Quantitative bacterial flora of acute appendicitis. Arch Dis Child. 1988;63:536-40.

14. Brook I. Bacterial studies of peritoneal cavity and postoperative surgical wound drainage following perforated appendix in children. Ann Surg 1980;192:208-12.

15. Pinto DJ, Sanderson PJ. Rational use of antibiotic therapy after appendicectomy. Br Med J 1980;280:275-7.

16. Berne TV, Yellin AE, Appleman MD, et al. Surgically treated gangrenous or perforated appendicitis: a comparison of aztreonam and clindamycin versus gentamicin and clindamycin. Ann Surg 1987;205:133-7. 